\section{Pinching Ornamental Sunflowers Increases Cut Stem Yield and Reduces Flower Size}

\author{
Hans C. Wien ${ }^{1}$
}

\begin{abstract}
AdDitional INDEX wORDs. branching, flowering delay, flower value, population response, cultivar effects, Helianthus annuus

SUMMARY. Most sunflower cultivars (Helianthus annums) grown as cut flowers produce single stems and do not form branches. If pinched (i.e., apical meristem removed) in the seedling stage, plants form branches from basal nodes. In four experiments conducted under field conditions, pinching seedlings increased the number of marketable sunflower stems per plant 2.6 to 4.6 times, but the flowers formed were reduced in diameter by $43 \%$, and flowering was delayed by 1 week to 10 days. Leaving six instead of four basal nodes after pinching only increased stem yield slightly in 2005 but not in 2006 . Increasing the space available per plant from $9 \times 9$ to $12 \times 12$ inches increased flower diameter of pinched and control plants from 7 to $7.9 \mathrm{~cm}$, but the resulting lower yield per unit area reduced overall value. In three out of four experiments, 'Procut Orange' produced more stems after pinching than 'Sunrich Orange'. Pinching nonbranching sunflowers is a promising technique, increasing yield by a factor of three, and the value of the harvested flowers by $82 \%$.
\end{abstract}

$\mathrm{T}$ he practice of removing an herbaceous plant's growing point (commonly termed pinching or topping) has been used for many centuries to affect growth, plant productivity, or shape (Escher, 1996; Hunt, 1893). Most commonly, pinching is used to reduce plant height and encourage branching (Faust, 2006). When used on cut flower species that typically only produce a single flower, pinching during the early vegetative stage, allows a multibranched plant to develop (Badge et al., 2014; Cheong et al., 2002; De Pascale et al., 2005).

Pinching has been practiced on many annual species used as cut flowers, including gypsophila [Gypsophila paniculata (Cheong et al., 2002)], lisianthus [Eustoma grandiflorum (De Pascale et al., 2005)], and african marigold [Tagetes erecta (Badge et al., 2014)]. In herbaceous perennials such as delphinium (Delphinium elatum) pinching of early shoots breaks apical dominance to encourage growth of secondary shoots (Garner et al., 1997). Although pinching of sunflowers is apparently widely practiced (Armitage and Laushman, 2003; Dole and Wilkins, 2005), scientific study of this topic has been limited. A l-year study in Mississippi determined that pinching increased yield of branching

Horticulture Section, School of Integrative Plant Science, Plant Science Hall, Cornell University, Ithaca, NY 14853

${ }^{1}$ Corresponding author. E-mail: hcw2@cornell.edu. doi: 10.21273/HORTTECH03502-16 more than nonbranching cultivars, but did not manipulate spacing nor include a nonpinched control treatment (Sloan and Harkness, 2010). The research presented here documents the effects of pinching and plant spacing on productivity and cut flower characteristics of two unbranched cultivars of sunflower.

\section{Materials and methods}

ExPTs. 1 AND 2. Seeds of 'Procut Orange' and 'Sunrich Orange' (Harris Seeds, Rochester, NY) were sown in a greenhouse in seedling trays (with 25 - and $55-\mathrm{mL}$ individual cell volumes in 2005 and 2006, respectively) filled with peat-vermiculite soil mix. During the seedling growth period of $22 \mathrm{~d}$, greenhouse temperatures were maintained at $24 \pm 2{ }^{\circ} \mathrm{C}$, and trays were fertigated with a $15 \mathrm{~N}-2.2 \mathrm{P}-12.5 \mathrm{~K}$ nutrient solution at the rate of $150 \mathrm{mg} \cdot \mathrm{L}^{-1}$ nitrogen (Peters Excel 15-5-15 Cal Mag; Scotts Miracle-Gro, Marysville, $\mathrm{OH}$ ) during weekdays and water only on weekends. Sowing dates were 6 June and 30 May in 2005 and 2006, respectively. Seedlings received ambient light and photoperiod in the greenhouse.

Seedlings were transplanted to an outdoor area near Ithaca, NY (lat. $42.42^{\circ} \mathrm{N}$, long. $76.50^{\circ} \mathrm{W}$ ), having sandy loam soil (coarse-loamy, mixed, active, mesic Lamellic Hapludalf). The field was fertilized with a $13 \mathrm{~N}-5.7 \mathrm{P}-10.8 \mathrm{~K}$ fertilizer (Phelps Supply, Phelps, NY) at $100 \mathrm{lb} /$ acre $\mathrm{N}$ that was incorporated into the soil before planting. Beds were 4 inches high and 40 inches wide, watered by two trickle irrigation lines, and covered with black polyethylene mulch. Seedlings were spaced $9 \times 9$ inches apart in four rows on each bed. There were 24 seedlings per treatment for each cultivar. The experiments had a two-way factorial treatment design with three replications.

The three treatments consisted of l) untreated (unpinched) controls, and removal of the plant growing point by hand or using pruners, leaving 2) four or 3) six expanding leaves or nodes, at about 1 week after transplanting. Shoots were harvested at anthesis, defined as the time when the majority of petals (ray flowers) had just unfolded to an angle of $90^{\circ}$ or more to the disk. Shoot length was measured from soil level to the top of the flower head for controls, and from the base of each branch to the top of the flower head for pinched plants. Flower disk diameter is the distance across the disk, ignoring petals. Leaf numbers included leaf scars at the stem base for controls, and leaves near the head that had visible petioles.

Data were analyzed using Statistix software (version 9; Analytical Software, Tallahassee, FL) to determine effects of the primary factors and their interactions on measured parameters. I used an analysis of variance (ANOVA) with means separation by Duncan's multiple range test. Since plant reaction to pinching was different in the 2 years, the analyses were not combined.

ExpTs. 3 AND 4. These experiments probed the effect of wider

\begin{tabular}{llll}
\hline $\begin{array}{l}\text { Units } \\
\text { To convert U.S. to SI, } \\
\text { multiply by }\end{array}$ & U.S. unit & SI unit & $\begin{array}{l}\text { To convert SI to U.S., } \\
\text { multiply by }\end{array}$ \\
\hline 29.5735 & $\mathrm{fl} \mathrm{oz}$ & $\mathrm{mL}$ & 0.0338 \\
0.0929 & $\mathrm{ft}^{2}$ & $\mathrm{~m}^{2}$ & 10.7639 \\
2.54 & inch $(\mathrm{es})$ & $\mathrm{cm}$ & 0.3937 \\
1.1209 & $\mathrm{lb} / \mathrm{acre}$ & $\mathrm{kg} \cdot \mathrm{ha}^{-1}$ & 0.8922 \\
1 & $\mathrm{ppm}$ & $\mathrm{mg} \cdot \mathrm{L}^{-1}$ & 1 \\
$\left({ }^{\circ} \mathrm{F}-32\right) \div 1.8$ & ${ }^{\circ} \mathrm{F}$ & ${ }^{\circ} \mathrm{C}$ & $\left({ }^{\circ} \mathrm{C} \times 1.8\right)+32$
\end{tabular}


Table 1. Stem yield, flowering time, stem length, and flower disk diameter for two sunflower cultivars in pinching Expt. 1 conducted in 2005. Plant apices were pinched leaving either four or six leaves in the seedling stage. Flowers were harvested at anthesis of the individual stems.

\begin{tabular}{|c|c|c|c|c|}
\hline Treatment & Stems (no./plant) & Time to flowering (d) & Stem length $(\mathrm{cm})^{\mathrm{z}}$ & Flower disk diam $(\mathrm{cm})$ \\
\hline 'Procut Orange' & 2.3 & 62 & 76 & 4.8 \\
\hline 'Sunrich Orange' & 2.4 & 73 & 100 & 6.6 \\
\hline Significance & NS & $* * *$ & $* * *$ & $* * *$ \\
\hline Control & $1.0 \mathrm{c}^{\mathrm{y}}$ & $63 \mathrm{~b}$ & $115 \mathrm{a}$ & $7.8 \mathrm{a}$ \\
\hline Pinched at leaf 4 & $2.6 \mathrm{~b}$ & $70 \mathrm{a}$ & $78 \mathrm{~b}$ & $5.0 \mathrm{~b}$ \\
\hline Pinched at leaf 6 & $3.5 \mathrm{a}$ & $70 \mathrm{a}$ & $72 \mathrm{~b}$ & $4.4 \mathrm{~b}$ \\
\hline
\end{tabular}

${ }^{\mathrm{z}} 1 \mathrm{~cm}=0.3937$ inch.

VValues in columns followed by the same letters are not significantly different at the $5 \%$ level using Duncan's multiple range test.

${ }^{* \star *}$ Significant $F$ test at $P \leq 0.001$ level, ${ }^{\text {Ns }}$ nonsignificant at $P \leq 0.05$.

spacing on flower size and yield in 2007 and 2008 and were conducted in a different part of the same field using the same fertility practices and the same cultivars. The trials compared a $9 \times 9$-inch spacing with four rows per bed with $12 \times 12$-inch spacing with three rows per bed. Seedlings were started in a greenhouse in early June in soilless mix and transplanted in mid June. Greenhouse growing conditions were similar to those in Expts. 1 and 2. Pinching consisted of apex removal, leaving four nodes, on 2 and 7 July for Expts. 3 and 4 , respectively. There were three replications and experimental design was a split plot in Expt. 3, with cultivars as main plots, and spacing and pinching in factorial combinations as subplots. In Expt. 4, a splitsplit plot design was used, with cultivars as main plots, pinching treatments as subplots, and plant spacing as sub-subplots. Statistix software was again used for statistical analysis of the data, using ANOVA and Duncan's multiple range test. The correlation and graph of flower diameter and stem yield was computed using SigmaPlot software (Systat Software, San Jose, CA).

Economic values of the harvested flowers were calculated using wholesale prices posted for the Boston wholesale flower market, assuming that disk diameters of less than $6 \mathrm{~cm}$ corresponds to the market designation of "small" ( $\$ 0.85$ per stem $), 6$ to $8 \mathrm{~cm}$ to "medium" $(\$ 1.00)$, and more than $8 \mathrm{~cm}$ to "large" (\$1.50) (USDA, 2016).

\section{Results and discussion}

EXPTS. 1 AND 2. Removing the stem apex when the plants had either four or six expanded leaves induced

Table 2. Leaf number on the main stem of two sunflower cultivars not pinched, and on the branches that formed after pinching, in a field experiment conducted in 2005. Plant apices were pinched leaving either four or six leaves in the seedling stage. The pinching $\times$ cultivar interaction was significant at the $1 \%$ level.

\begin{tabular}{lcc}
\hline & 'Procut Orange' & 'Sunrich Orange' \\
\cline { 2 - 3 } Treatment & \multicolumn{2}{c}{ Leaves (no.) } \\
\hline Not pinched & $20 \mathrm{~d}^{\mathrm{z}}$ & $24 \mathrm{e}$ \\
Pinched leaf 4 & $8 \mathrm{~b}$ & $15 \mathrm{c}$ \\
Pinched leaf 6 & $6 \mathrm{a}$ & $15 \mathrm{c}$ \\
\hline
\end{tabular}

${ }^{\mathrm{z}}$ Values in columns followed by the same letters are not significantly different at the $5 \%$ level using Duncan's multiple range test.

branching and increased yields from 1 to 2.6 and 3.5 stems per plant in Expt. 1, respectively (Table 1). In Expt. 2, stem yields increased four times due to pinching, with 'Procut Orange' showing a slightly higher yield from pinching than 'Sunrich Orange' (Table 3). Pinching at node six instead of node four increased yield slightly in 2005 but not in 2006 .

Flowering was delayed $7 \mathrm{~d}$ by pinching in Expt. 1, and by 9 to $10 \mathrm{~d}$ in Expt. 2, with a significantly greater delay for 'Sunrich Orange' (Tables 1 and 3). Plants pinched at node six flowered slightly later than those pinched at node four, leading to a significant cultivar by pinching interaction in Expt. 2. 'Sunrich Orange' flowered 12 to $14 \mathrm{~d}$ later than 'Procut Orange' in both experiments.

Pinching of 'Sunrich Orange' in Expt. 1 resulted in branches with 15 leaves, compared with 24 leaves on the primary stem of control plants. In 'Procut Orange', branches had significantly fewer leaves, averaging seven in comparison with 20 on the primary stem of control plants (Table 2).

Although the branch stems produced by pinching were significantly shorter than those of control plants, stem lengths in all treatments were in proportion to the reduced flower disk diameter. 'Sunrich Orange' produced $25 \%$ longer stems than 'Procut Orange' in both years. Flower size, as measured by the disk diameter, was reduced by $40 \%$ and $49 \%$ for Expts. 1 and 2 , respectively, by pinching. In 2006 , the size reduction was greater for 'Sunrich Orange' than for 'Procut Orange', resulting in a significant cultivar by pinching interaction (Table $3)$. As disk diameter is diminished to $4 \mathrm{~cm}$, consumer appeal of sunflowers is also reduced, as indicated by a reduced price per stem on the Boston wholesale flower market, from $\$ 1.50$ for large to $\$ 0.85$ for small flowers (USDA, 2016).

Pinched 'Procut Orange' plants showed a significant incidence of malformed flowers in 2005, with irregular disk shapes, and petals forming in the disks. The misshapen flowers were not included in the yield analysis. 'Sunrich Orange' had a much lower incidence of this disorder, but since it flowered later than 'Procut Orange', it is difficult to know if this is a cultivar difference, or due to an interaction of the cultivar with the climate at the time. A linkage of flower deformation with cool temperatures was reported by Yamaguchi et al. (2014) with gypsophila. This disorder did not occur in 2006. 
EXPTS. 3 AND 4. The effect of pinching on the two sunflower cultivars was similar to what was observed in Expts. 1 and 2. Pinching increased stem yields by a factor of 3.6, delayed flowering by $6 \mathrm{~d}$, and resulted in smaller flowers on shorter stems (Tables 4 and 5 ). In both experiments,
'Procut Orange' produced more stems after pinching than 'Sunrich Orange', leading to a significant cultivar $\times$ pinching interaction (Tables 4 and 5). A similar difference in productivity of pinched sunflowers was also found by Sloan and Harkness (2010). As in Expt. 2, flowering was delayed less by pinching for 'Procut Orange' than 'Sunrich Orange' in Expt. 4 (Table 5).

Widening the spacing between plants produced a slight increase in stem yield per plant, more so for the pinched plants, resulting in a significant pinching by spacing interaction (Tables 4 and 5). Spacing the plants more widely

Table 3. The interaction of pinching and cultivar on stem yield, flowering date, leaf number, and stem and flower size of two cultivars of sunflower as affected by pinching the plants at the four- or six-leaf stage. Data are from Expt. 2 , conducted in 2006. Flowering stems were harvested at anthesis of each main stem or branch.

\begin{tabular}{|c|c|c|c|c|c|}
\hline Treatment & Stems (no./plant) & Time to flowering (d) & Leaves (no.) & Stem length $(\mathrm{cm})^{\mathrm{z}}$ & Flower disk diam $(\mathrm{cm})$ \\
\hline 'Procut Orange' control & $1.0 \mathrm{a}^{\mathrm{y}}$ & $56 \mathrm{a}$ & $19 \mathrm{~d}$ & $123 \mathrm{c}$ & $7.5 \mathrm{c}$ \\
\hline 'Procut Orange' pinch leaf 4 & $4.7 \mathrm{c}$ & $63 \mathrm{~b}$ & $10 \mathrm{~b}$ & $69 \mathrm{a}$ & $4.4 \mathrm{~b}$ \\
\hline 'Procut Orange' pinch leaf 6 & $4.5 \mathrm{c}$ & $65 \mathrm{c}$ & $8 \mathrm{a}$ & $69 \mathrm{a}$ & $3.7 \mathrm{a}$ \\
\hline 'Sunrich Orange' pinch leaf 4 & $3.5 \mathrm{~b}$ & $77 \mathrm{e}$ & $16 \mathrm{c}$ & $85 \mathrm{~b}$ & $4.8 \mathrm{~b}$ \\
\hline 'Sunrich Orange' pinch leaf 6 & $3.6 \mathrm{~b}$ & $77 \mathrm{e}$ & $11 \mathrm{~b}$ & $79 \mathrm{ab}$ & $4.8 \mathrm{~b}$ \\
\hline
\end{tabular}

${ }^{\mathrm{z}} 1 \mathrm{~cm}=0.3937$ inch.

y Values in columns followed by the same letters are not significantly different at the $5 \%$ level using Duncan's multiple range test.

${ }^{*},{ }^{* *},{ }^{* *}$ Significant $F$ test at $P \leq 0.05,0.01,0.001$ level, respectively.

Table 4. Effect of the interaction of spacing with pinching averaged across 'Procut Orange' and 'Sunrich Orange' sunflowers and the interaction of cultivars and pinching on stem yield, earliness of flowering, stem length, and size of the flower in a field experiment in 2007 (Expt. 3). Stems were pinched at the four-leaf stage, and flowering stems were harvested at anthesis of the individual stems.

\begin{tabular}{|c|c|c|c|c|}
\hline Treatment $^{\mathrm{z}}$ & Stems (no./plant) & Time to first flower $(\mathrm{d})$ & Stem length $(\mathrm{cm})^{\mathrm{z}}$ & Flower diam $(\mathrm{cm})$ \\
\hline $9 \times 9$ inches control & $1.0 \mathrm{a}^{\mathrm{y}}$ & 65 & $123 \mathrm{c}$ & 8.6 \\
\hline $9 \times 9$ inches pinched & $3.3 \mathrm{~b}$ & 71 & $59 \mathrm{a}$ & 5.4 \\
\hline $12 \times 12$ inches control & $1.0 \mathrm{a}$ & 64 & $118 \mathrm{c}$ & 9.6 \\
\hline $12 \times 12$ inches pinched & $3.8 \mathrm{c}$ & 69 & $72 \mathrm{~b}$ & 6.2 \\
\hline Interaction significance & * & NS & ** & NS \\
\hline 'Procut Orange' control & $1.0 \mathrm{a}$ & 61 & 110 & 8.8 \\
\hline 'Sunrich Orange' pinched & $2.8 \mathrm{~b}$ & 75 & 72 & 6.2 \\
\hline Interaction significance & $* * *$ & NS & NS & NS \\
\hline
\end{tabular}

${ }^{\mathrm{z}} \mathrm{l}$ inch $=2.54 \mathrm{~cm}, \mathrm{l} \mathrm{cm}=0.3937$ inch.

${ }^{\mathrm{y}}$ Values in columns followed by the same letters are not significantly different at the $5 \%$ level using Duncan's multiple range test.

${ }^{*}, * *, * *$ Significant $F$ test at $P \leq 0.05,0.01,0.001$ level, respectively, ${ }^{\text {Ns }}$ nonsignificant at $P \leq 0.05$.

Table 5. Effect of the interaction of spacing and pinching, and of cultivar with pinching on stem yield, earliness of flowering, stem length, and size of the flower in a field experiment in 2008 (Expt. 4). Sunflower plants were grown at two spacings and pinched at the four-leaf stage, and the stems were harvested at anthesis of the individual stems.

\begin{tabular}{|c|c|c|c|c|}
\hline Treatment $^{\mathrm{z}}$ & Stems (no./plant) & Time to first flower $(\mathrm{d})$ & Stem length $(\mathrm{cm})^{\mathrm{z}}$ & Flower diam $(\mathrm{cm})$ \\
\hline $9 \times 9$ inches control & $1.0 \mathrm{a}^{\mathrm{y}}$ & 63 & $155 \mathrm{c}$ & 8.8 \\
\hline $9 \times 9$ inches pinched & $2.5 \mathrm{~b}$ & 69 & $96 \mathrm{a}$ & 5.4 \\
\hline $12 \times 12$ inches control & $1.0 \mathrm{a}$ & 63 & $145 \mathrm{~b}$ & 9.8 \\
\hline $12 \times 12$ inches pinched & $2.8 \mathrm{c}$ & 68 & $98 \mathrm{a}$ & 6.1 \\
\hline Interaction significance & * & NS & ** & NS \\
\hline 'Procut Orange' control & $1.0 \mathrm{a}$ & 58 a & 136 & $9.2 \mathrm{c}$ \\
\hline 'Sunrich Orange' pinched & $2.2 \mathrm{~b}$ & $76 \mathrm{~d}$ & 107 & $6.4 \mathrm{~b}$ \\
\hline Interaction significance & ** & $* * *$ & NS & ** \\
\hline
\end{tabular}

${ }^{\mathrm{z}} 1$ inch $=2.54 \mathrm{~cm}, \mathrm{l} \mathrm{cm}=0.3937$ inch

'Values in columns followed by the same letters are not significantly different at the $5 \%$ level using Duncan's multiple range test.

${ }^{*},{ }^{* *},{ }^{* *}$ Significant $F$ test at $P \leq 0.05,0.01$, and 0.001 level, respectively, ${ }^{\text {Ns }}$ nonsignificant at $P \leq 0.05$. 
Table 6. Stem yields, flower diameters, and economic value of two sunflower cultivars grown at $9 \times 9$-inch $(22.9 \mathrm{~cm})$ or $12 \times$ 12 -inch $(30.5 \mathrm{~cm})$ spacing, and pinched in the seedling stage in 2007 (Expt. 3) and 2008 (Expt. 4). Economic value was calculated from current prices on the Boston wholesale flower market, assigning flowers of less than $6 \mathrm{~cm}$ diameter to small $(\$ 0.85), 6$ to $8 \mathrm{~cm}$ to medium (\$1.00), and larger than $8 \mathrm{~cm}$ to large flower size $(\$ 1.50)($ USDA, 2016).

\begin{tabular}{|c|c|c|c|c|c|c|c|c|}
\hline \multicolumn{9}{|c|}{ Flower yield (stems $\left./ 1,000 \mathrm{ft}^{2}\right)^{\mathrm{z}}$} \\
\hline \multicolumn{5}{|c|}{$9 \times 9$ inches } & \multicolumn{4}{|c|}{$12 \times 12$ inches } \\
\hline \multirow[b]{2}{*}{ Cultivar } & \multicolumn{2}{|c|}{ Control } & \multicolumn{2}{|c|}{ Pinched } & \multicolumn{2}{|c|}{ Control } & \multicolumn{2}{|c|}{ Pinched } \\
\hline & Expt. 3 & Expt. 4 & Expt. 3 & Expt. 4 & Expt. 3 & Expt. 4 & Expt. 3 & Expt. 4 \\
\hline Procut Orange & 222 & 222 & 895 & 637 & 167 & 167 & 763 & 551 \\
\hline Sunrich Orange & 222 & 222 & 562 & 460 & 167 & 167 & 513 & 384 \\
\hline \multicolumn{9}{|c|}{ Flower diam $(\mathrm{cm})^{\mathrm{z}}$} \\
\hline \multicolumn{9}{|c|}{ Economic value $(\$)$} \\
\hline Procut Orange & 333 & 333 & 761 & 541 & 250 & 250 & 648 & 468 \\
\hline Sunrich Orange & 333 & 333 & 478 & 460 & 250 & 250 & 513 & 384 \\
\hline
\end{tabular}

${ }^{\mathrm{z}} 1 \mathrm{stem} / 1,000 \mathrm{ft}^{2}=10.7639 \mathrm{stems} / 1,000 \mathrm{~m}^{2}, 1 \mathrm{~cm}=0.3937$ inch.

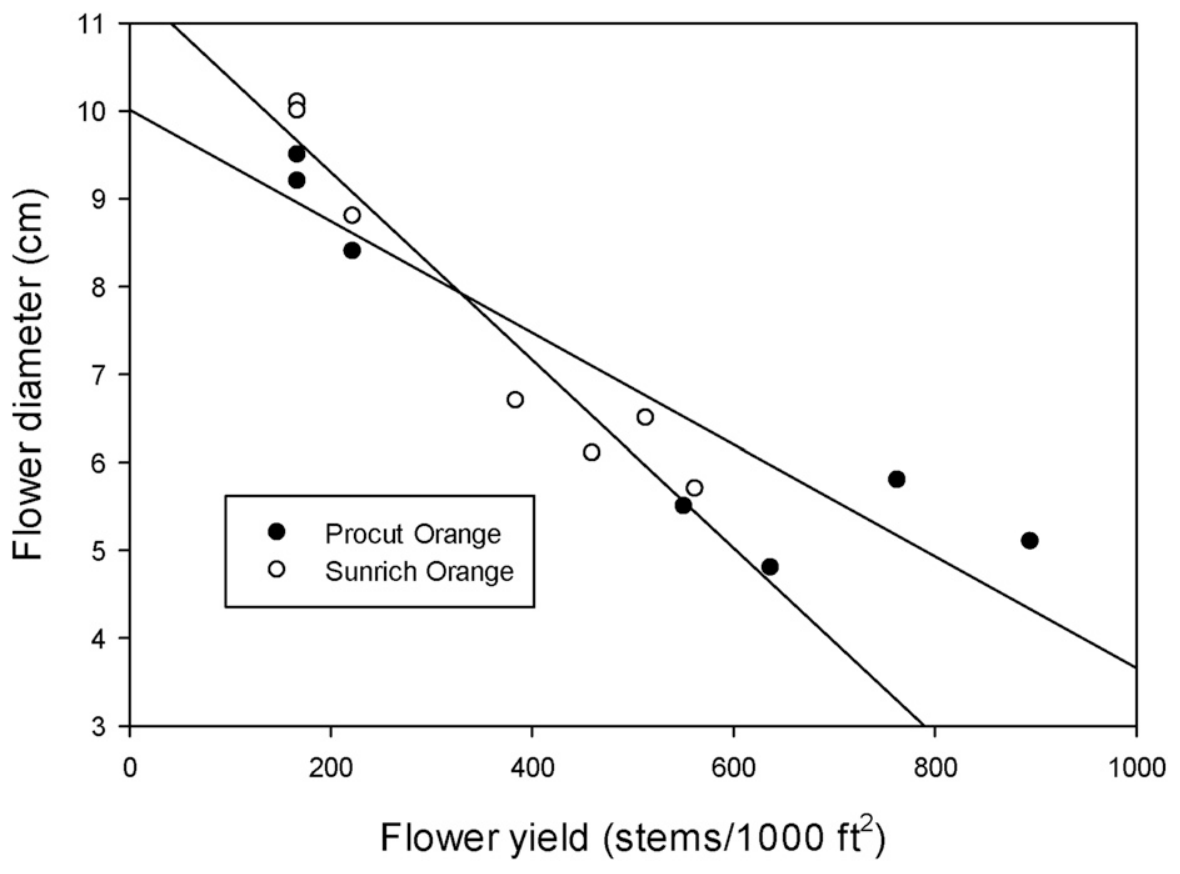

Fig. 1. Relationship between sunflower yield and flower head diameter, combined for Expts. 3 and 4 . Sunflowers of two cultivars were grown at either $9 \times 9$-inch $(22.9 \mathrm{~cm})$ or $12 \times 12$-inch $(30.5 \mathrm{~cm})$ spacing and pinched at the four-leaf stage, and the stems harvested at anthesis of the individual stems. Line equations are $y=$ $10.02-0.0064 \times\left(r=0.93^{* *}\right)$ for 'Procut Orange' (full circles) and $y=11.44-$ $0.107 \times\left(r=0.97^{* *}\right)$ for 'Sunrich Orange' (open circles); 1 stem $/ 1000 \mathrm{ft}^{2}=$ 10.7639 stems $/ 1000 \mathrm{~m}^{2}, 1 \mathrm{~cm}=0.3937$ inch.

allowed the branches on pinched plants to grow longer than when crowded into the $9 \times 9$-inch spacing. Flower heads were larger at the wide spacing, whether the plants were pinched or not. A combination of wide spacing and pinching resulted in heads of intermediate size compared with control plants grown at either spacing, or pinched plants grown at $9 \times 9$-inch spacing.

When stem yields are expressed on a land area basis, pinching increased stem yields per unit area by a factor of three, and the value of harvested flowers by $82 \%$ (Table 6 ). Thus in spite of the reduction in flower size due to pinching, the higher yields more than compensated for the reduced value of the smaller flowers. Pinched 'Procut Orange' plants were $48 \%$ more productive than pinched 'Sunrich Orange', and this translated into 32\% more value in the market. These results and the findings of Sloan and Harkness
(2010) point out the need to further investigate the cultivar responses to pinching of sunflower cultivars. The economic advantages of sunflower pinching deserve wider publicity in form of demonstration plots and extension bulletins.

As the number of stems or branches per unit area increased, flower size decreased linearly (Fig. 1). Population studies with sunflowers have documented a similar relationship between plant population (i.e., density, plant number per unit area) and head size (Majid and Schneiter, 1987; Robinson et al., 1980). The relationship between plant density and head size appears to vary according to cultivar, with plant density increase resulting in a steeper decline in head size for 'Sunrich Orange' than for 'Procut Orange'. This increased sensitivity of 'Sunrich Orange' to stem density also occurred in 2006 (Table 3). The results imply that if stem density were increased to extremes, head diameter would decrease to nonmarketable size.

The dramatic increase in stem yield per plant caused by pinching occurred in all four experiments (Tables $1-5$ ), and parallels work by others on lisianthus (De Pascale et al., 2005). The branches formed primarily on the first four nodes of the plant, so leaving the additional two nodes only occasionally increased yield (Tables 1 and 3 ). The cultivars used in this study do not produce branches if not pinched even if spaced widely, and are branching only in response to removal of apical dominance due to pinching.

Pinching of nonbranching sunflowers is, thus, a practice that should 
be more widely practiced to increase yield and income without the expense of increasing plant populations. Drawbacks of the labor requirements of pinching, l-week delay in flowering, and occasional increases in malformation of the flowers of the pinched plants may limit use of the technique, but are offset by a significant increase in crop value.

\section{Literature cited}

Armitage, A.M. and J.M. Laushman. 2003. Specialty cut flowers. 2nd ed. Timber Press, Portland, OR.

Badge, S., D.M. Panchbhai, and V.N. Dod. 2014. Response of pinching and foliar application of gibberellic acid on growth and flower yield in summer African marigold. Res. Crops 15:394-397.

Cheong, D.C., J.S. Jeong, J.S. Choi, and H.B. Park. 2002. Effect of planting date and pinching on flowering and cut flower yield of Gypsophila paniculata in subalpine areas. J. Korean Soc. Hort. Sci. 43:773776.

De Pascale, S., P. Di Muccio, S. Fiorenza, and R. Paradiso. 2005. Effect of the planting density, pinching and illumination on flowering of lisianthus. Colture Protette 34(11):77-84.

Dole, J.M. and H.F. Wilkins. 2005. Floriculture principles and species. Pearson Prentice Hall, Upper Saddle River, NJ.

Escher, F. 1996. Schnittblumenkulturen. 4th ed. Verlag Eugen Ulmer, Stuttgart, Germany.

Faust, J.E. 2006. Building the plant chassis with manual and chemical pinching. OFA Bul. 896:21-24.

Garner, J.M., S.A. Jones, and A.M. Armitage. 1997. Pinch treatment and photoperiod influence flowering of $\mathrm{Del}$ phinium cultivars. HortScience 32:61-63.

Hunt, M.A. 1893. How to grow cut flowers. Moore and Langen, Terra Haute, IN.
Majid, H.R. and A.A. Schneiter. 1987. Yield and quality of semidwarf and standardheight sunflower hybrids grown at five plant populations. Agron. J. 79:681-684.

Robinson, R.G., J.H. Ford, W.E. Lueschen, D.L. Rabas, L.J. Smith, D.D. Warnes, and J.W. Wiersma. 1980. Response of sunflower to plant population. Agron. J. 72:869-871.

Sloan, R.C. and S.S. Harkness. 2010. Planting date and pinch treatments affect growth of field-grown cut flower sunflower cultivars. Mississippi Agr. For. Expt. Sta. Bul. 1180.

U.S. Department of Agriculture (USDA). 2016. Boston ornamental terminal prices. 23 Mar. 2016. <http://www.ams.usda. gov/mnreports/bh.fx201.txt>.

Yamaguchi, N., T. Goto, and K. Kobiki. 2014. Effect of minimum air temperature on occurrence of abnormal inflorescence and cut flower quality in Gypsophila paniculata 'Altair'. Hort. Res. 13:161-167. 